\title{
The Impact of Asnaf Entrepreneur's Intention Towards Decision and the Movement of Zakat Collection
}

\author{
Noormariana Mohd Din ${ }^{1}$, Mohd Zulkifli Muhammad ${ }^{1}$, Mohammad Ismail ${ }^{1} \&$ Nadzirah Mohd Said $^{1}$ \\ ${ }^{1}$ Faculty of Entrepreneurship and Business, Universiti Malaysia Kelantan, Jalan Pengkalan Chepa, Kota Bharu, \\ Kelantan, Malaysia \\ Correspondence: Noormariana Mohd Din, Faculty of Entrepreneurship and Business, Universiti Malaysia Kelantan, \\ Jalan Pengkalan Chepa, 16100 Kota Bharu, Kelantan, Malaysia. E-mail: mariana.md@umk.edu.my
}

Received: July 19, 2020

doi:10.5430/rwe.v11n6p284
Accepted: September 15, 2020

Online Published: December 20, 2020

URL: https://doi.org/10.5430/rwe.v11n6p284

\begin{abstract}
Decision is an issue that needs to be explored in detail due to its relationship to an individual's psychology. In the context of zakat that also acts as microfinancing (non-refundable fund), decision plays an important role in terms of collection and distribution. However, previous literature about zakat has not clarified this phenomenon especially in the context of Asnaf entrepreneurs. Asnaf entrepreneurs represent micro entrepreneurs who depend on zakat funds. Then, by benefiting the funds and getting support from the zakat institutions, Asnaf entrepreneurs become less dependent on the support and become zakat payers. Therefore, grounded by Theory of Planned Behaviour (TPB) framework, the purpose of this paper is to investigate the impact of Asnaf Intention's towards decision as the zakat payers. A total of 274 Asnaf entrepreneurs from Kelantan and Selangor had participated in this study. Data were collected through self-administered survey questionnaires. The main statistical technique used in this study is Structural Equation Modelling (SEM) by using Analysis of Moment Structure (AMOS) version 23. The study has shown that subjective norms are found to be most dominant predictor towards decision closely followed by attitude, and perceived behavioural control. The above findings have added several implications towards theory, both practical and managerial. In general, the findings of the study are consistent with the theory of planned behaviour. Moreover, Asnaf entrepreneur's intention gives the better impact towards decision and zakat collection.
\end{abstract}

Keywords: asnaf, entrepreneurs, intention, decision

\section{Introduction}

An individual's intention concerning a change in future actions is directly related to their willingness to do so. This, in turn, is broadly related to the sociology and psychology of individuals. Compliance behaviour is a challenging issue, as it relates to human decision- making which will change from time to time (Devos, 2013). These are predominantly influenced by the conditions of the economy and social factors, both of which serve as prerequisites for further understanding a useful framework for decision studies (Damayanti, Subekti, \& Baridwan, 2015). In Malaysia, intention is integrated into economic, psychological, and social models that are generally explored in taxation studies. In terms of taxation, tax payers' sociology and psychology play important roles in capturing future actions and intention (Chen Loo, McKerchar, \& Hansford, 2009). Interestingly, this fruitful conceptualization was also earlier explored in the field of Islamic taxation. One of the Islamic taxations that is a major main focus in Al Quran is zakat (Jalili, 2006). Zakat is the compulsory tax paid by Muslims, which is extremely important in Muslim society's economic and social development. The prevalence of Islamic taxation refers to the relationship between humans and Allah SWT. This relationship can be exerted to various degrees of faith and religious belief.

Discordance in this relationship may result in punishment in the life of the Hereafter as mentioned in Surah At Talaq: 8;

"And how many [people of] a city were insolent toward the command of [their] Lord and His messengers, so We took them to severe account and punished [them] with a terrible punishment".

Since zakat is considered a mandatory obligation for Muslims from Allah SWT, human actions regarding this matter have to be fulfilled by a man; but, once the requirement of zakat is achieved, it is no longer an obligation until the next year. Failure to fulfill the obligation means that the man will be punished in the Hereafter; or, in other words, by Allah SWT. Moreover, in an Islamic context, the ideal human behaviour and decision has been mentioned and prescribed in 
Al Quran and Sunnah through Shariah. Several studies have touched on decision with an Islamic taxation perspective (Khamis, Kamarudin, Hashim., 2018; Khamis, Salleh \& Nawi, 2014; Muhammad, 2016; Sulaiman, 2019; Syakir, Mohd Noor, \& Wahid, 2018). Generally, these studies supported decision acts as the main contribution towards zakat collection. It merely shows that the importance of understanding compliance behavior is heavily controlled by zakat payers' decisions. Nevertheless, Ahmad, Othman and Salleh (2015) indicated the amount of wealth reserved for zakat payment is governed by certain factors, which will eventually influence such compliancy. Due to that, the issue of compliance toward zakat payment is seen as a serious issue since zakat plays a major role as contributor toward Malaysia's economy (Mahfuzha et al., 2019). Zakat also helps to fulfill the necessities of recipients by programs such as Islamic microfinance. This microfinance is a form of monetary capital in equipment which helps a recipient improve their standard of living (Bakar \& Abdghani, 2011). Moreover, it is also one of the mechanisms for minimizing intragroup income inequality through the microfinance program (Samir, 2019). This program is supported by the funds, which are acquired from zakat payments, to integrate microentreprise which lacks access to capital from formal financial institutions (Junaidi, 2011). The implementation of this microfinance, which is a form of capital assistance, provides a positive impact for its recipients (Mustahiq). Based on Hafas Furqani (2018), the recipient can solve the problem of inequalities in society and poverty. Moreover, they can be transformed from a recipient (Mustahiq) to a zakat payer (Muzakki) through capital assistance. However, the recipient (Mustahiq) should maintain their productivity after receiving the capital assistance by producing something that has added value (Suprayitno, 2013). The intention of paying zakat has been supported and well discussed by previous scholars (Faizah, 2014; Fiqhyany \& Prasetyo, 2015). It is understood that the individuals' intention to pay zakat may have a superior impact toward their future payment behavior. In addition, the concept of intention in zakat was mentioned by Rasulullah S.A.W;

"Intend for Allah swt (for the sake of citizenship and justice) what you are giving to the state. And verily the zakat act is dependent on its intention".

Therefore, this research attempts to bridge the gap in Asnaf entrepreneurs' intention that may give the impact the decision towards zakat on business.

\section{Review of Asnaf Entrepreneurs}

In Malaysia, Asnaf entrepreneurs have also been supported by other facilities, which was not only limited to capital, but also permitted exposure to important facilities such as training, marketing, and financial management for their business (Hazlina Abdul et al., 2012). Through these facilities, Asnaf entrepreneurs successfully show off their capabilities and commitments in business. The capabilities and commitments of Asnaf entrepreneurs in business provide a positively impact for the future. Nurbani Md Hassan \& Rom (2016) found that the Asnaf entrepreneurs were able to show a positive improvement in business after zakat institutions gave the capital assistance and training needed. This improvement enhanced Asnaf entrepreneurs' contributions to the economy and society through zakat.

In wealth creation, the present study focused on the business group of Asnaf entrepreneurs. A wealth creation mechanism is created through distribution practiced by Asnaf entrepreneurs through payment of zakat to other recipients. This mechanism attempts to improve practices of the Asnaf entrepreneurs to be good Muslims while helping lower income individuals through their business as well, which has been mentioned in Surah Al Baqarah: 267. This verse emphasizes the good things, including zakat, when it remarks that it is better to give than to receive in order to be a good Muslim.

"O ye who believe! Give of the good things which you have honourably earned and out of that which we bring forth for you from the earth of the fruits of the earth which we have produced for you".

Thus, based on the above verse, it is important to encourage the collection of zakat, starting with the perfect practices of Asnaf entrepreneurs, who are the recipients of zakat as represented by their being micro entrepreneurs. In order to access an Asnaf's interests, certain requirement were obtained such as, first, an interest in the subject matter and, second, a willingness to study; third, the physical capability to run the business. In terms of the types of zakat recipients, Lembaga Zakat Selangor (2016) explained the three types of zakat recipients under AEP as stated below;

i. Asnaf who is not able to do anything except to continue his own life;

ii. Asnaf is one who needs assistance in order for him to face or exit the situation; and

iii. Asnaf is one who is currently under hardship but has a potential to develop, grow and graduate from the Asnaf status

With these types of recipients, Rahman \& Ahmad (2011) named the productive Asnafs who were strong mentally and physically towards business in order to train and advance from the Asnaf status to another status (Salleh, Abdullah, \& 
Hamat, 2011). Generally, this training was conducted under the Asnaf Entrepreneurial Programme (AEP) which had been the focus for Small Medium Enterprises (SMEs) training for Asnaf entrepreneurs in particular. The key performance indicator for this AEP was to graduate the Asnaf to a non Asnaf status. Moreover, it also gave opportunity to Asnaf entrepreneurs to become a micro position in an upper level category that is the part that participates in SMEs known as ex Asnaf (Mohieldin, Iqbal, Rostom, \& Fu, 2012). The implementation of Asnaf entrepreneurs is illustrated by zakat institutions' distribution, referred to in Figure 1, which is known as the "Turning Over Model" that basically distributed zakat to potential Asnaf for business (Sabri \& Hasan, 2006), then, the Asnaf underwent a process of forming and enhancing the business with the aid of the zakat and were monitored by the zakat institution.

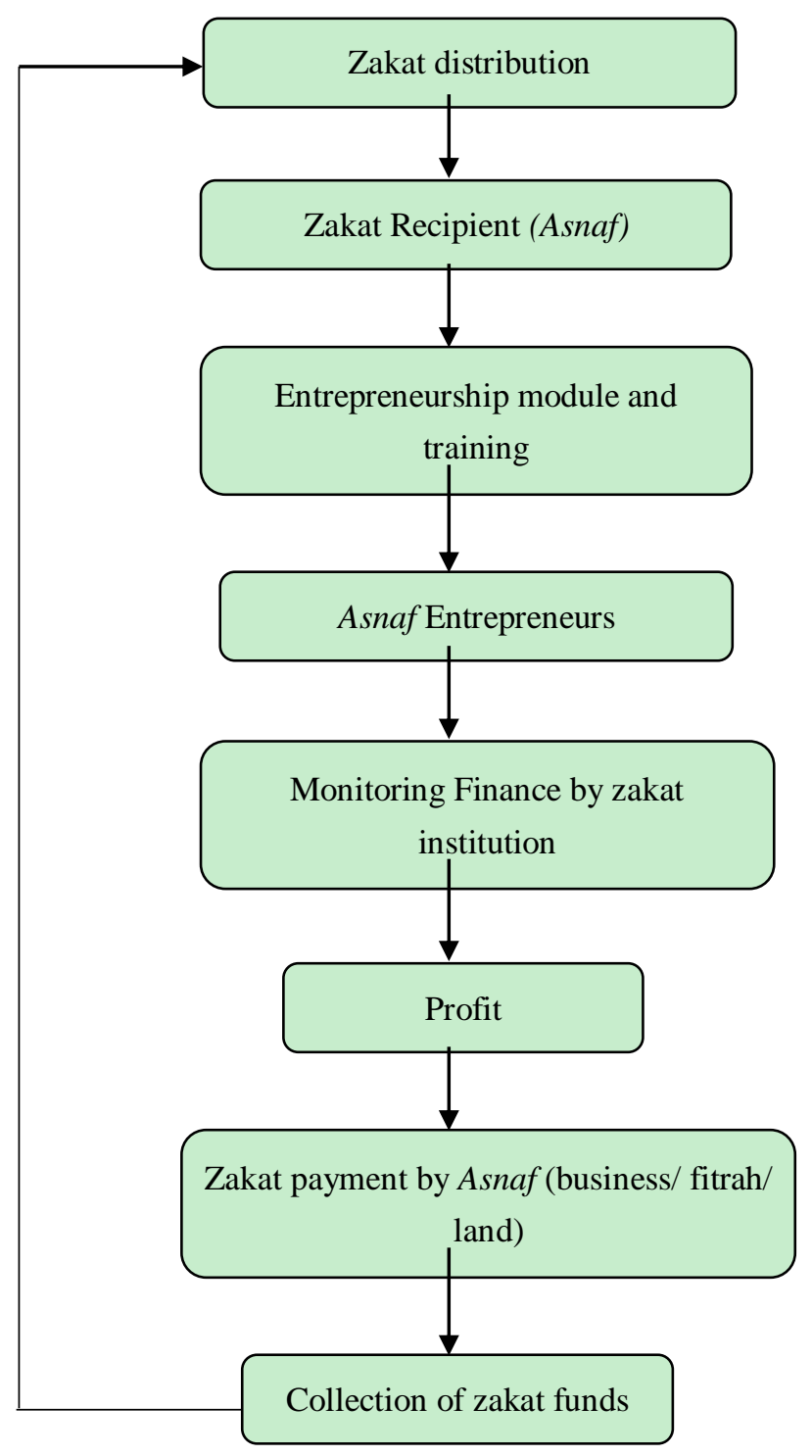

Figure 1. Turning over model

\section{Research Methodology}

A research design provides the basic direction for carrying out a study that related the research questions or hypothesis accurately and objectively (Hair, 2006). This proposed study is correlational in nature since the primary objective is to identify variables that might influence Asnaf entrepreneur's compliance behaviour towards zakat on business. This correlational study conducted in a natural environement with minimal researcher's interference 
(Sekaran \& Bougie, 2013). Hence, a survey method has been employed as it is the most appropriate method in this study. This method mostly suitable due to the fact that the study's purpose is to generalise from a sample to a population. It is can be made the better inferences to the characteristics and behaviour of the population (Creswell, 2014).

\subsection{Research Instruments}

This study used paper-based questionnaire as the instrument for the survey, and by used the dual-languages, which is English and translation in Malay language. These dual languages used to ensure the content validity in questionnaire. The set of questionnaires will be divided by two sections. The first section consists of demographic information and next section implores about the variables of interest in this study, which is behaviour, intention, attitude and its decomposed components, subjective norms and its decomposed components, perceived behavioural control and its decomposed components, as well as spiritual quotient and its components.

This condition shown that the higher of encouragement and supports from the government in terms of capital sources and training. These supports give the effect in established Kelantan act as entrepreneurship state. In addition, by develop the Asnaf Entrepreneurial Programme (AEP) it is expected to fast-track the positive economic values and significant impact in inspiring the living standard among Asnaf in the future (Maheran, 2014). Moreover, this program monitored by the Majlis Agama Islam Kelantan (MAIK). The population that listing provided by the MAIK indicates Asnafs involved in (AEP) since 2011-2014 are 933 Asnafs. The information provided by MAIK indicate that $45 \%, 420$ of Asnafs under poor status is high motivated in the business. Based on that percentage, Asnafs who are experienced in the business under AEP also acts as the zakat payers to support others Asnaf based on income and business sustainable.

Meanwhile, this study also chose Selangor as a second state. This state was chosen as well as Lembaga Zakat Selangor (LZS) well known as the success institutions in distribution of zakat. In addition, majority previous studies focused on the Selangor state in investigated the zakat distribution issue as such (Ab Rahman, 2014; Aza Shahnaz Azman, 2014; Hazlina Abdul et al., 2012; Jamaliah et al., 2014; M. Jamaliah, Sharifah Norzehan, , 2014; Sanep Ahmad, 2009). The selected sample size will also guide by the 5\% level of significant at which the formulated hypotheses will be test. This level of significance is standard that specified for rejecting the null hypothesis.

Table 1. Sample size distribution

\begin{tabular}{lll}
\hline & Population & Sample size \\
\hline Kelantan & 420 & 131 \\
Selangor & 457 & 143 \\
Total & 877 & 274 \\
\hline
\end{tabular}

\section{Data Analysis}

Data analysis involves steps such as coding the responses, screening the data, and selecting the appropriate data analysis strategy. These steps presented by Churchill \& Iacobucci (2010), starting by identifying data entry errors and examine how appropriately the data meets the statistical assumptions. The screening involves running descriptive, missing, outliers, response bias, normality, multicollinearity and reliability of data. Then, it supported another several statistical tools and methods were employed for data analysis and hypotheses testing by using SPSS software version 18. This tool will be supported the analysing data by Structural Equation Modeling (SEM) using AMOS 18.0 software. SEM was used to manage the measurement and structural model concurrently. The next section discussed the detail discussion on the analysis technique employed in this study.

\subsection{The Pooled-CFA to Validate the Measurement Model for All Constructs}

The study needs to assess the Discriminant Validity among all constructs in the model. For this purpose, the study needs to combine all constructs together and execute the CFA at once using the popularly known as Pooled-CFA. Since the models are second-order, it would be too complicated if all constructs are combined, the study need to simplify all second order constructs to become first order. Thus, the study needs to obtain the composite mean for every sub-construct of the measurement model. 


\subsection{Structural Model Analysis}

After assesses the measurement model, achieved the goodness of fit model, convergent and discriminant validity, then the model was applied into structural model. In this model, purposely for determine the relationship among constructs and to achieve the hypotheses in this study. The Asnaf entrepreneur's compliance behavior (CB) and Asnaf's Intention are the endogenous variables which are determined by exogenous variables namely attitude, subjective norms, perceived behavioral control and Spiritual Quotient. The goodness of fit measured as well as same in the confirmatory factor analysis stage. The goodness of fit indices has shown satisfactory results. The structural model fit to the data with value of $\mathrm{ChiSq} / \mathrm{df}=1.462$ the $\mathrm{CFI}=0.970, \mathrm{IFI}=0.971$, TLI=0.966, NFI=0.912, RFI=0.901 and root mean RMSEA $=0.041$. It shows that, all fit indices were achieved. It shows that all the indices value exceeded the commonly accepted levels, indicating that the model can be used to determine the hypothesis in this study.

\subsection{Relationship Between Asnaf's Intention and Attitude, Subjective Norms and Perceived Behaviour Control}

The direct relationship between Asnaf's Intention and dimension for Asnaf entrepreneur's compliance behavior tabulated in Table 2. It indicated the relationship between Asnaf's intention and Attitude is supported ( $\beta=0.199$; C.R $=1.887 ; \rho<0.05$ ). For relationship between Asnaf's intention and Subjective norms, the results revealed that $(\beta=0.134 ; \mathrm{C} . \mathrm{R}=1.653 ; \rho<0.001)$. Next, the relationship between Asnaf's intention and Perceived behavior control it also found that the significant relationship which is $(\beta=0.110 ; C . R=1.309 ; \rho<0.001)$.

Table 2. Results of asnaf's intention and attitude, subjective norms and perceived behavioural control

\begin{tabular}{lllll}
\hline $\begin{array}{l}\text { Relationship between } \\
\text { exogenous } \\
\text { andogenous variables }\end{array}$ & $\begin{array}{l}\text { Standardized } \\
\text { coefficient } \\
(\boldsymbol{\beta})\end{array}$ & $\begin{array}{l}\text { Critical } \\
\text { Ratio } \\
(\mathbf{C R})\end{array}$ & $\boldsymbol{\rho}$ value & Results \\
\hline Int $<--$ ATT & 0.199 & 1.887 & $0.022^{* * *}$ & Supported \\
Int $<-$ SN & 0.134 & 1.653 & $0.001^{* * *}$ & Supported \\
Int <-- PBC & 0.110 & 1.309 & $0.001^{* * *}$ & Supported \\
\hline
\end{tabular}

Note: Int= Asnaf's intention, ATT=Attitude, $\mathrm{SN}=$ Subjective Norms and $\mathrm{PBC}=$ Perceived Behavioural Control, $* \rho<0.01, * * \rho<0.05, * * * \rho<0.001$.

\subsection{Hypothesis Testing for Mediator Effects of Analysis of Generated Model}

This study examined the mediating effect of Asnaf's Intention in the relationship between predictor factors with Asnaf entrepreneur's compliance behaviour. The mediating effect between both variables done by make comparison based on significant value between direct and indirect relationship. The findings of mediating effect are discussed as follows.

4.5 Mediating Effect of Asnaf's Intention in the Relationship Between Attitude, Subjective Norms, Perceived Behaviour Control and Asnaf Entrepreneur's Compliance Behaviour

The study found that Asnaf's intention played an important role as full mediator of some of the relationship between predictor variable and Asnaf entrepreneur's compliance behavior. It was also found as a partial mediator for other relationship, while it did not mediate the rest of of the predictors. All the results for direct and indirect path by using bootstrapping results tabulated in Table 3 .

Table 3. Results of hypothesis testing for asnaf's intention and attitude, subjective norms and perceived behavioural control

\begin{tabular}{|c|c|c|c|c|c|}
\hline \multirow[t]{2}{*}{ Paths } & \multicolumn{3}{|c|}{ Bootstrapping Result } & \multirow[t]{2}{*}{ Result } & \multirow[t]{2}{*}{ Hypothesis } \\
\hline & Direct Effects & & Indirect Effects & & \\
\hline ATT $\rightarrow$ Int $\rightarrow$ Dec & 0.365 & $>$ & 0.201 & Not Mediate & Not supported \\
\hline $\mathrm{SN} \rightarrow \mathrm{Int} \rightarrow$ Dec & 0.395 & $<$ & 0.41 & Full mediation & Supported \\
\hline $\mathrm{PBC} \rightarrow \operatorname{Int} \rightarrow$ Dec & 0.03 & $<$ & 0.28 & Partial Mediation & Supported \\
\hline
\end{tabular}

Note: Dec=Decision, Int= Asnaf's intention, $\mathrm{ATT}=$ Attitude, $\mathrm{SN}=$ Subjective Norms and $\mathrm{PBC}=$ Perceived Behavioural Control 
First effect of Asnaf's intention in the relationship between Attitude and Asnaf entrepreneur's compliance behaviour as presented in Table 3. The path of direct relationship ATT $\rightarrow$ Dec was 0.365 was greater than indirect effect ATT $\rightarrow$ Int $\rightarrow$ Dec 0.201 . Thus, the H5(d) is rejected. The next hypothesis H5(e) is the effect of Asnaf's intention in the relationship between subjective norms and Asnaf entrepreneur's compliance behaviour. It indicates that this hypothesis was supported whereas the direct effect less than indirect effect. Next hypothesis is examining the Asnaf's intention in the relationship between perceived behavioural control and Asnaf entrepreneur's decision. The result shows that it is partial mediation and supported the H5(f). the partial incurred since the direct effect for perceived behavioural control to Asnaf entrepreneur's compliance behaviour is significant.

\section{Discussion}

Based on the research objective and questions, this study significantly examines the impacts of an Asnaf entrepeneur's intention towards decision zakat on business. The Decomposed Theory of Planned Behaviour (DTPB) as stated by Taylor and Todd (1995) was undertaken as a basis for developing the research framework. This theory supports three factors positively affecting an individual's action. The DTPB decomposes the three factors into specific beliefs. However, this study includes an intention, as a mediator construct, into the model then examines its impact towards an Asnaf entrepreneur's decision. This section includes a discussion of the results beginning with a discussion of the first level constructs, (Attitude, Subjective Norms, and Perceived Behavioural Control), and their relationship. Secondly, a discussion on the second level constructs (Attitude, Subjective Norms, and Perceived Behavioural Control) will be discussed. Next, the results which are related to an Asnaf entrepreneur's intentions that influence the Asnaf entrepreneur's decision towards zakat from business will be argued. The discussions cover the effects of the mediating variable towards its relationship between attitude, subjective norms, perceived behavioural control, and an Asnaf entrepreneur's decision.

\section{Conclusion}

In conclusion, the study presents how the research objectives in this study were obtained through an elaborated discussion of the results. This study completely examined the utilization of the Theory of Planned Behaviour (TPB) and decomposed the TPB. By using the decomposed TPB, it provided an expansive set of antecedents so that effect could be better explained to measure decision. Hence, it supported the theoretical and practical contributions of this study. Furthermore, the results of this study show a positive relationship for all hypotheses.

\section{References}

Ab Rahman, A. (2014). Memformulasi Model Produktif Pembangunan Program Usahawan bagi Memperkasakan Ekonomi Golongan Asnaf. Paper presented at the Persidangan Kebangsaan Ekonomi Malaysia ke-9 (PERKEM ke-9) "Urus Tadbir Ekonomi yang Adil: Ke Arah Ekonomi Berpendapatan Tinggi", Kuala Terengganu,Terengganu.

Aza, S. A. (2014). Knowledge understanding in complying zakah: Evaluation of Goodness-Fit Indices using Structural Equation Models. Paper presented at the Proceeding of the International Conference on Masjid, Zakat and Waqf (IMAF 2014), Kuala Lumpur.

Bakar, M. H. A., \& Abdghani, A. H. (2011). Towards achieving the quality of life in the management of zakat distribution to the rightful recipients (the poor and needy). International Journal of Business and Social Science, 2(4).

Chen Loo, E., McKerchar, M., \& Hansford, A. (2009). Understanding the compliance behaviour of Malaysian individual taxpayers using a mixed method approach. J. Australasian Tax Tchrs. Ass'n, 4, 181.

Churchill, G. A., \& Iacobucci, D. (2010). Marketing research: methodological foundations.

Damayanti, T. W., Subekti, I., \& Baridwan, Z. (2015). Trust and uncertainty orientation: An efforts to create tax compliance in social psychology framework. Procedia-Social and Behavioral Sciences, 211, 938-944.

Devos, K. (2013). Factors influencing individual taxpayer compliance behaviour. Springer Science \& Business Media.

Faizah, R. (2014). Zakat hasil laut dalam perspektif para juragan nelayan: Studi di Desa Kranji Kecamatan Paciran Kabupaten Lamongan. Universitas Islan Negeri Maulana Malik Ibrahim.

Fiqhyany, M. R., \& Prasetyo, A. (2015). Pengaruh Komunikasi Pemasaran Terpadu Terhadap Niat Muzakki Membayar Dana Zakat, Infaq, Shadaqah Pada Yayasan Nurul Hayat Cabang Tuban. Jurnal Ekonomi Syariah Teori dan Terapan, 1(11).

Hafas Furqani, R. M., \& Fahmi, Y. (2018). Zakat for Economic Empowerment of The Poor in Indonesia: Models and 
Implications. Jurnal Kajian Ekonomi dan Binis Islam, 11(2).

Hair, J. F. (2006). Multivariate data analysis. Pearson Education India.

Hazlina Abdul, Said, J., \& Yusuf, S. N. S. (2012). Individual characteristics of the successful asnaf entrepreneurs: Opportunities and solutions for zakat organization in Malaysia. International Business and Management, 4(2), 41-49.

Jalili, A. R. (2006). A Descriptive Overview of Islamic Taxation. Journal of American Acedemy of Business, 8(2), 16-28.

Jamaliah, H., Saad, H. A., Yusuf, S. N. S., \& Smith, M. (2014). A comparative study of successful male and female entrepreneurs: The case of the Selangor Zakat Board (SZB). International Review of Social Sciences and Humanitiess, 7(1), 125-135.

Junaidi, E., \& Rizkiyah, P. D. (2011). Does contract type influence the Zakat, Infaq and Shadaqah donation of Islamic Microfinance customers? Case study of Baitul Maal Wat Tamwil Beringharjo, Yogyakarta, Indonesia. Paper presented at the 8th International Conference on Islamic Economics and Finance.

Khamis, M. R., Kamarudin, M. F., Hashim, M. J., \& Arifin, N. A. M. . (2018). Length of business operation and its relationship with compliance behaviour of business Zakat among owners of SMEs. Journal of Emerging Economies \& Islamic Research, 6(3), 69-82.

Khamis, M. R., Mohd, R., Salleh, A. M., \& Nawi, A. S. (2014). Do religious practices influence compliance behaviour of business zakat among SMEs?. Journal of Emerging Economies and Islamic Research (JEEIR), 2(2).

Lembaga Zakat Selangor. (2015). Laporan Kutipan dan Agihan Zakat di Selangor Bulan Januari-September 2012-2015. Retrieved from Selangor.

Lembaga Zakat Selangor. (2017). Zakat Selangor raikan usahawan Asnaf.

Maheran, N. A. A. (2014). Effects of human needs based on the integration of needs as stipulated in Maqasid Syariah and Maslow's Hierarchy of needs on zakah distribution efficiency of asnaf Assistance Business Program. Jurnal Pengurusan, 40, 41-52.

Mahfuzha, A., Zakia Rizki, C., Sapha, D., Fitriyani, F., Jamal, A., \& Weri, W. (2019). Is Zakat Important in Reducing Poverty

Muhammad, I. (2016). Factors That Influence Business Zakat Compliance Among Small And Medium Entrepreneurs.

Samir, N. (2019). Making Zakat and Aid Work in Poor Economics (Vol. 16).

Sanep Ahmad. (2009). Agihan Zakat Merentasi Asnaf: Ke Arah Memperkasa Institusi Zakat. Prosiding PERKEM (Persidangan Kebangsaan Ekonomi Malaysia) IV, Jilid, 2.

Sekaran, U., \& Bougie, R. (2010). Research Methods for Business: A Skill. Building Approach. UK: John Wiley.

Sekaran, U., \& Bougie, R. (2013). Edisi 6. Research Methods for Business.

Sekaran, U., \& Bougie, R. (2016). Research methods for business: A skill building approach. John Wiley \& Sons.

Sulaiman, Y., Rahman, M. A., \& Mat, N. K. N. (2019). The Conceptual Paper on Service Quality and Business Zakat Compliance Behaviour among SMEs in Kedah. Journal of Accounting, Business and Finance Research, 5(1), 23-28.

Suprayitno, E., Abdul Kader, R., \& Harun, A. (2013). The impact of zakat on aggregate consumption in Malaysia. Journal of Islamic Economics, Banking and Finance, 113(912), 1-24.

Syakir Rurol Mukhan, A., Mohd Noor, M. A., \& Wahid, H. (2018). Jangkaan Kepatuhan Membayar Zakat Perniagaan Di Kalangan Usahawan Di Selangor: Cadangan Menggunakan Peranti Bizzakat. Paper presented at the Persidangan Kebangsaan Ekonomi Malaysia ke-13 2018.

\section{Copyrights}

Copyright for this article is retained by the author(s), with first publication rights granted to the journal.

This is an open-access article distributed under the terms and conditions of the Creative Commons Attribution license (http://creativecommons.org/licenses/by/4.0/). 